\title{
Dichotomous role of pancreatic HUWE1/MULE/ARF-BP1 in modulating beta cell apoptosis in mice under physiological and genotoxic conditions
}

\author{
Linyuan Wang • Cynthia T. Luk • Stephanie A. Schroer • Alannah M. Smith • Xie Li • \\ Erica P. Cai • Herbert Gaisano • Patrick E. MacDonald - Zhenyue Hao • Tak W. Mak • \\ Minna Woo
}

Received: 24 February 2014 / Accepted: 14 May 2014 /Published online: 1 July 2014

(C) Springer-Verlag Berlin Heidelberg 2014

\begin{abstract}
Aims/hypothesis Diabetes mellitus represents a significant burden on the health of the global population. Both type 1 and type 2 diabetes share a common feature of a reduction in functional beta cell mass. A newly discovered ubiquitination molecule HECT, UBA and WWE domain containing 1, E3 ubiquitin protein ligase (HUWE1 [also known as MULE or
\end{abstract}

Electronic supplementary material The online version of this article (doi:10.1007/s00125-014-3295-8) contains peer-reviewed but unedited supplementary material, which is available to authorised users.

L. Wang $\cdot$ C. T. Luk $\cdot$ S. A. Schroer $\cdot$ E. P. Cai $\cdot$ M. Woo $(\bowtie)$

Toronto General Research Institute, University Health Network, MaRS Ctre, TMDT, 101 College St, 10th floor, Rm 10-363, Toronto, ON, Canada M5G 1L7

e-mail: mwoo@uhnresearch.ca

L. Wang $\cdot$ T. W. Mak $\cdot$ M. Woo

Department of Medical Biophysics, University of Toronto, Toronto, ON, Canada

L. Wang $\cdot$ C. T. Luk $\cdot$ H. Gaisano $\cdot$ Z. Hao $\cdot$ T. W. Mak $\cdot$ M. Woo Faculty of Medicine, University of Toronto, Toronto, ON, Canada

C. T. Luk $\cdot$ E. P. Cai $\cdot$ M. Woo

Institute of Medical Science, University of Toronto, Toronto, ON, Canada

A. M. Smith • P. E. MacDonald

Department of Pharmacology and Alberta Diabetes Institute,

University of Alberta, Edmonton, AB, Canada

X. Li $\cdot$ H. Gaisano

Department of Physiology, University of Toronto, Toronto, ON,

Canada

M. Woo

Division of Endocrinology and Metabolism, Department of

Medicine, University Health Network, Toronto, ON, Canada
ARF-BP1]) is a critical regulator of p53-dependent apoptosis. However, its role in islet homeostasis is not entirely clear. Methods We generated mice with pancreas-specific deletion of Huwel using a Cre-loxP recombination system driven by the $P d x 1$ promoter $\left(P d x l c r e^{+} H_{u w e} I^{\mathrm{fl} / \mathrm{ll}}\right)$ to assess the in vivo role of HUWE1 in the pancreas.

Results Targeted deletion of Huwel in the pancreas preferentially activated p53-mediated beta cell apoptosis, leading to reduced beta cell mass and diminished insulin exocytosis. These defects were aggravated by ageing, with progressive further decline in insulin secretion and glucose homeostasis in older mice. Intriguingly, Huwel deletion provided protection against genotoxicity, such that $P d x l$ cre $^{+} H u w e I^{\mathrm{fl} / \mathrm{fl}}$ mice were resistant to multiple-lowdose-streptozotocin-induced beta cell apoptosis and diabetes. Conclusion/interpretation HUWE1 expression in the pancreas is essential in determining beta cell mass. Furthermore, HUWE1 demonstrated divergent roles in regulating beta cell apoptosis depending on physiological or genotoxic conditions.

Keywords Apoptosis · ARF-BP1 $\cdot$ Beta cell $\cdot$ Diabetes HUWE1 · MULE

$\begin{array}{ll}\begin{array}{l}\text { Abbreviations } \\ \text { Cm } \\ \text { c-Myc }\end{array} & \begin{array}{l}\text { Membrane capacitance } \\ \text { V-myc avian myelocytomatosis viral oncogene } \\ \text { homologue }\end{array} \\ \text { GSIS } & \begin{array}{l}\text { Glucose-stimulated insulin secretion } \\ \text { HUWE1 }\end{array} \\ & \begin{array}{l}\text { HECT, UBA and WWE domain containing 1, E3 } \\ \text { ubiquitin protein ligase }\end{array} \\ \text { MCL1 } & \begin{array}{l}\text { Myeloid cell leukaemia sequence 1 } \\ \text { MDM2 }\end{array} \\ \text { Mouse double minute 2 homologue } \\ \text { MLDS } & \begin{array}{l}\text { Multiple low dose streptozotocin } \\ \text { PDX1 }\end{array} \\ \text { Pancreatic and duodenal homeobox 1 } & \text { Streptozotocin }\end{array}$




\section{Introduction}

Type 1 diabetes is characterised by the autoimmune destruction of insulin-producing beta cells and typically has an early onset, while type 2 diabetes is associated with obesity and insulin resistance [1, 2]. Although caused by distinct underlying mechanisms, one common feature is an inadequate number of beta cells, which are required to maintain a sufficient plasma insulin level for glucose homeostasis.

Increased apoptotic cells have been observed in islets of patients with both type 1 and type 2 diabetes, in association with dramatic reduction in beta cell mass $[1,3]$. The wellknown tumour suppressor $\mathrm{p} 53$, when activated, leads to cell cycle arrest and apoptosis. It can be induced by a variety of insults, including DNA damage, oncogenic expression and ribosomal stress $[4,5]$. The p53-dependent apoptotic pathway plays a critical role in beta cell demise during diabetes pathogenesis. The expression of p53 is increased in both human amylin- and nitric oxide-induced beta cell apoptosis in culture $[6,7]$. In addition, beta-cell-specific p53 stabilisation and upregulation has been implicated in beta cell mass reduction in humans with diabetes $[8,9]$. On the other hand, deletion of p53 in beta cells in culture provides resistance from NEFAinduced apoptosis [10]. Furthermore, p53-null mice are protected from streptozotocin (STZ)-induced beta cell death and type 1 diabetes [11], which suggests that p53 plays an important regulatory role in beta cell homeostasis under both physiological and pathological conditions. Thus, p53 and its regulators represent a viable target for diabetes.

For years, mouse double minute 2 homologue (MDM2) has been touted as the principle inhibitor of $\mathrm{p} 53$, via its specific E3 ubiquitin ligase activity leading to $\mathrm{p} 53$ degradation [12]. However, MDM2-null cells continue to undergo p53 stabilisation and subsequent apoptosis [13], suggesting an MDM2-independent regulation of p53. Indeed, multiple studies have shown molecules that directly regulate $\mathrm{p} 53$ function without MDM2 [14-16]. One such molecule is myeloid cell leukaemia sequence 1 (MCL1) ubiquitin ligase E3 (MULE) or HECT, UBA and WWE domain containing 1, E3 ubiquitin protein ligase (HUWE1 [also known as ARF-BP1 or LASU1]). The Huwel gene is encoded on the $\mathrm{X}$-chromosome and its protein product contains multiple domains, including $\mathrm{BH} 3$, which allows for polyubiquitination and degradation of p53 independent of MDM2 [17]. Thus, HUWE1 may have a regulatory role in p53-mediated apoptosis of beta cells that occurs during diabetogenesis.

Apart from p53, HUWE1 has multiple other polyubiquitination substrates [18-22]. Among them is MCL1, which belongs to the anti-apoptotic B cell CLL/lymphoma 2 (BCL-2) family of proteins [20]. MCL1 is rapidly induced after exposure to cell damaging stimuli, thus offering acute protection against apoptosis [23]. Therefore, from a functional point of view, the interaction of HUWE1 with MCL1 is pro-apoptotic in nature. This is in direct contrast to the anti-apoptotic role of HUWE1 in its polyubiquitination of p53. Therefore, it is very likely that the role of HUWE1 is cell-type- and context-specific [24], and the function of HUWE1 in beta cell homeostasis and diabetes pathogenesis remains unclear.

In this study, we examined the role of HUWE1 in beta cells by targeted deletion of Huwel in mouse pancreas. Under basal conditions, we observed an overall anti-apoptotic role of HUWE1, predominantly through its inhibition of p53. As such, HUWE1-deficient mice showed a decline in beta cell mass with ageing without essential involvement of other known substrates of HUWE1 under physiological conditions. Furthermore, we showed that HUWE1 was critical for modulating exocytosis of insulin granules in beta cells. Intriguingly, Huwel deletion demonstrated an opposite effect in response to genotoxic stress, whereby HUWE1-deficient beta cells were resistant to streptozotocin (STZ)-induced apoptosis and diabetes. Thus, HUWE1 is a critical modulator of beta cell integrity and function under both physiological and pathological conditions.

\section{Methods}

Mice Heterozygote Huwe ${ }^{\mathrm{fl} / \mathrm{y}}$ mice (Tak Mak, Toronto, ON, Canada; exons 76 and 77 of Huwel flanked by loxP sites) were bred with Pdxlcre mice (Jackson Laboratories, Bar Harbor, ME, USA) $[25,26]$ to generate male $P d x 1$ cre $^{+}$ Huwe I $^{+/ \mathrm{y}}$, male Pdxlcre Huwel $^{\mathrm{fl} / \mathrm{y}}$, female Pdxlcre Huwel $^{+/+}$and female Pdxlcre Huwel ${ }^{\text {fl/fl }}$ mice. Male mice were used for experiments and littermates as controls. Genotypes were determined as described previously [27]. Mice were maintained on a mixed 129J-C57BL/6 background and housed in a pathogen-free facility on a $12 \mathrm{~h}$ light/dark cycle and fed ad libitum with standard irradiated rodent chow (5\% fat; Harlan Tecklad, Indianapolis, IN, USA) without restriction of activity in accordance with University Health Network Animal Care Facility Protocol.

Metabolic studies Serum insulin, blood glucose, glucose tolerance tests, insulin tolerance tests and glucosestimulated insulin secretion (GSIS) tests were performed as previously described [28]. Serum insulin was measured by enzyme-linked immunosorbent assay kit (Crystal Chem, Downers Grove, IL, USA).

STZ protocol Low doses of STZ were injected i.p. into mice (40 mg/kg body weight) for 5 days (consecutive) [29].

Immunohistochemistry and immunofluorescence The pancreas was fixed, stained and islet area quantified as previously 
described [27]. Antibodies against insulin (Dako, Glostrup, Denmark), glucagon (Cell Signaling Technology, Beverly, MA, USA), HUWE1 (Santa Cruz Biotechnology, Santa Cruz, CA, USA), TUNEL (Cell Signaling Technology), GLUT2 (Cell Signaling Technology), PDX1 (Santa Cruz Biotechnology), p53 (Cell Signaling Technology), p-p53 (Cell Signaling Technology) and MCL1 (Cell Signaling Technology) were used.

Western blotting Liver, muscle, visceral adipose tissue, islets and hypothalamus protein lysates were obtained as previously described [27]. Antibodies against actin (Santa Cruz Biotechnology), AMPK (Cell Signaling Technology), p-AMPK (Cell Signaling Technology), Akt (Cell Signaling Technology), p-Akt (Cell Signaling Technology), cleaved caspase 3 (Cell Signaling Technology), DNA polymerase beta (Abcam, Cambridge, MA, USA), GLUT2 (Chemicon, Temecula, CA, USA), MCL1 (Cell Signaling Technology), HUWE1 (Cell Signaling Technology), p53 (Cell Signaling Technology), PDX1 (Chemicon) were used.

Quantitative PCR RNA was extracted and quantitative (q)PCR performed as previously described $[28,30]$.

Electrophysiology Recording pipettes were from $1.5 \mathrm{~mm}$ borosilicate glass capillary tubes using a programmable micropipette puller. Pipettes were heat-polished and tip resistance ranged from 2 to $3 \mathrm{~m} \Omega$ when filled with intracellular solution. For measurement of membrane capacitance, the intracellular solution contained: $125 \mathrm{mmol} / \mathrm{l}$ caesium glutamate, $10 \mathrm{mmol} / \mathrm{l}$ $\mathrm{CsCl}, 10 \mathrm{mmol} / \mathrm{l} \mathrm{NaCl}, 1 \mathrm{mmol} / 1 \mathrm{MgCl}_{2}, 5 \mathrm{mmol} / 1 \mathrm{HEPES}$, $0.05 \mathrm{mmol} / \mathrm{l} \mathrm{EGTA}, 3 \mathrm{mmol} / \mathrm{l} \mathrm{MgATP}, 0.1 \mathrm{mmol} / \mathrm{l} \mathrm{cAMP,} \mathrm{pH}$ to 7.2. The extracellular solution consisted of $118 \mathrm{mmol} / \mathrm{l}$ $\mathrm{NaCl}, 5.6 \mathrm{mmol} / \mathrm{l} \mathrm{KCl}, 1.2 \mathrm{mmol} / \mathrm{l} \mathrm{MgCl} 2,10 \mathrm{mmol} / 1 \mathrm{CaCl}_{2}$, $20 \mathrm{mmol} / 1$ tetraethylammonium chloride, $5 \mathrm{mmol} / \mathrm{l}$ HEPES and $5 \mathrm{mmol} / \mathrm{l}$ D-glucose, $\mathrm{pH}$ 7.4. Cell membrane capacitance $(\mathrm{Cm})$ was estimated by the LindauNeher technique, implementing the 'sine-DC' feature of the Lock-in module ( $40 \mathrm{mV}$ peak-to-peak and a frequency of $500 \mathrm{~Hz}$ ) in the whole-cell configuration. Recordings were conducted using an EPC10 patch clamp amplifier and the Pulse and X-Chart software programs (HEKA Electronik, Lambrecht, Germany).

Statistics Data are presented as means \pm SEM and were analysed by one-sample $t$ test.

\section{Results}

Generation of pancreas-specific Huwe1-knockout mice HUWE1 protein was ubiquitously expressed. It was detected in islets, hypothalamus, muscle, liver and visceral adipose tissue in both females and males, and expression was similar in both sexes (Fig. 1a and electronic supplementary material [ESM] Fig. 1a, b). The expression of Huwel was significantly higher in pancreatic islets compared with surrounding exocrine tissue, indicating its potential important role in endocrine pancreatic function (Fig. 1b and ESM Fig. 1c).

The mouse Huwel gene is located on the X-chromosome. To generate mice with Huwel deletion specifically in pancreatic progenitor cells during early pancreatic development (E8.5-9), we employed the Cre-loxP system with cre expression regulated by the pancreas-specific promoter of pancreatic and duodenal homeobox 1. Both adult male Pdxlcre Huwel $1^{\mathrm{fl} / \mathrm{y}}$ mice and female Pdxlcre Huwe $^{+} \mathrm{fl}^{\mathrm{l} / \mathrm{fl}}$ mice showed dramatic reduction in Huwel mRNA (Fig. 1c and ESM Fig. 1d) in isolated islets. This translated into a significant reduction in HUWE1 protein (Fig. 1a and ESM Fig. 1a) and immunohistochemistry (Fig. $1 \mathrm{~b}$ and ESM Fig. 1c). $P d x l$ promoter expression has also been reported in the central nervous system, especially the hypothalamus, the command centre for many endocrine functions such as glucose and energy homeostasis. However, in our model no observable reduction in HUWE1 protein level was detected in isolated hypothalami from Pdxlcre Huwe $^{\mathrm{fl} / \mathrm{y}}$ or Pdxlcre $\mathrm{Huwel}^{\mathrm{fl} / \mathrm{fl}}$ mice compared with control littermates (Fig. 1a and ESM Fig. 1a). Accordingly, total body weight, a major hypothalamic regulatory target, remained similar to controls in both sexes (ESM Fig. 2a-d). The levels of HUWE1 protein was also comparable between genotypes in other peripheral tissues, including liver, muscle and visceral fat (Fig. 1a and ESM Fig. 1a).

Pdxlcre ${ }^{+}$Huwe ${ }^{f l y}$ mice demonstrated age-dependent glucose intolerance and beta cell dysfunction without changes in insulin sensitivity Male Pdxlcre Huwe $^{\mathrm{fl} / \mathrm{y}}$ mice showed similar fed blood glucose levels as controls (Fig. 2a) and by 2 months of age, exhibited higher fasting glucose levels (Fig. 2b). At this age, Pdxlcre ${ }^{+}$Huwel $^{\mathrm{fl} / \mathrm{y}}$ mice also showed a trend towards increased glucose excursion during glucose tolerance test (Fig. 2c), while no difference in glucose lowering in response to peripheral insulin injection was seen (Fig. 2d). This metabolic defect worsened with age, with significantly impaired glucose tolerance at 6 months of age (Fig. 2e), while insulin sensitivity remained unchanged (Fig. 2f). This glucose intolerance following $P d x 1$ promotermediated Huwel deletion was observed only in male mice, while female Pdxlcre ${ }^{+}$Huwe $^{\mathrm{fl} / \mathrm{fl} l}$ mice showed comparable blood glucose, glucose tolerance and peripheral insulin sensitivity between genotypes (ESM Fig. 3a-d), which may have been affected by female hormones $[31,32]$. Thus, only male Pdxlcre $^{+}$Huwe I $^{\mathrm{fl} / \mathrm{y}}$ and control male Pdxlcre HuweI $^{+/ \mathrm{y}}$ littermates were used for further investigations. 
Fig. 1 Pancreas-specific deletion of Huwe1. (a) Western blot of HUWE1 and actin protein in tissues from male $P d x 1 \mathrm{cre}^{+}$ HuweI $^{+/ y}(+/ \mathrm{Y})$ and Pdxlcre Huwe $^{\mathrm{fl} / \mathrm{y}}(-/ \mathrm{Y})$, and female Pdxlcre HuweI $^{+/+}(+/+)$and Pdxlcre Huwe $^{\mathrm{fl} / \mathrm{fl}}(-/-)$ mice with quantification for male mice $(n=5)$. (b) Representative immunohistological staining of HUWE1 protein in pancreatic sections ( $n=5$ mice). (c) Huwe1 mRNA expression in islets $\left(n=5\right.$ mice). ${ }^{*} p<0.05$. White bars, $+/ \mathrm{Y}$; black bars, $-/ \mathrm{Y}$ a


b

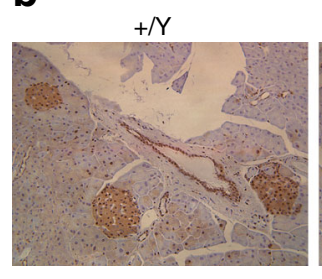

C



Impaired glucose tolerance without a significant defect in peripheral insulin sensitivity in male $P d x l$ cre $^{+}$ Huwe $1^{\mathrm{fl} / \mathrm{y}}$ mice suggested an insulin secretory defect. In line with this hypothesis there was a reduction in circulating insulin levels at both 2 and 6 months of age in these mice (Fig. 3a, b). Furthermore, in vivo GSIS was diminished in these mice at 2 months of age (Fig. 3c), and this secretory defect was further aggravated at 6 months of age (Fig. 3d). Thus, PDX1-mediated Huwel deletion impaired insulin secretion while sparing the peripheral metabolic actions of insulin.

Fig. 2 Absence of HUWE1 leads to impaired glucose tolerance in male Pdxlcre Huwe $^{\mathrm{fl} / \mathrm{y}}$ mice. (a) Fed and (b) fasting blood glucose levels of $P d x 1$ cre $^{+}$ Huwe I $^{+/ y}(+/ \mathrm{Y})$ and Pdxlcre Huwe $^{\mathrm{fl} / \mathrm{y}}(-/ \mathrm{Y})$ mice at 1 and 2 months of age $(n=9)$. (c) Glucose and (d) insulin tolerance test at 2 months of age $(n=7)$. (e) Glucose and (f) insulin tolerance test at 6 months of age $(n=7)$. ${ }^{*} p<0.05 \mathrm{vs}+/ \mathrm{Y}$ mice at the same age. White bars/squares, $+/ Y$; black bars/triangles, $-/ Y$ a

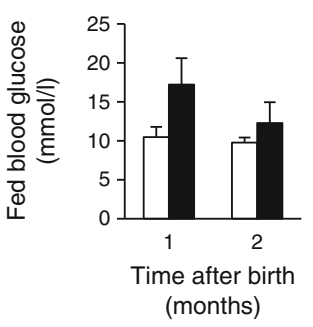

d

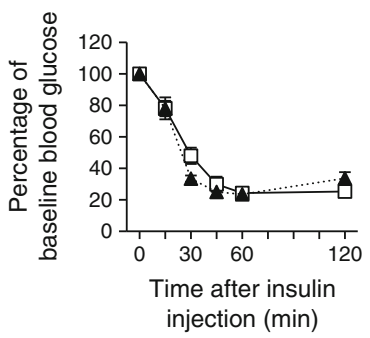

Pdxlcre ${ }^{+}$Huwe $^{f l y}$ islets demonstrated age-dependent reduction in beta cell mass and increase in apoptosis Total insulin secretion is the product of beta cell mass and secretory capacities of individual beta cells. Pancreatic sections from Pdxlcre Huwe $^{\mathrm{fl} / \mathrm{y}}$ mice showed a reduced total beta cell area at 2 months (ESM Fig. 4a, b) and further reduction at 6 months of age (Fig. $4 \mathrm{a}, \mathrm{b}$ ). In order to explore the mechanism of reduced beta cell mass in Pdxlcre Huwe $^{\mathrm{fl} / \mathrm{y}}$ pancreas, we measured their basal islet proliferation rate by Ki67 staining. Similar percentages of proliferating cells were observed in Pdxlcre Huwe $^{\mathrm{fl} / \mathrm{y}}$ and control islet tissue at both 2 and
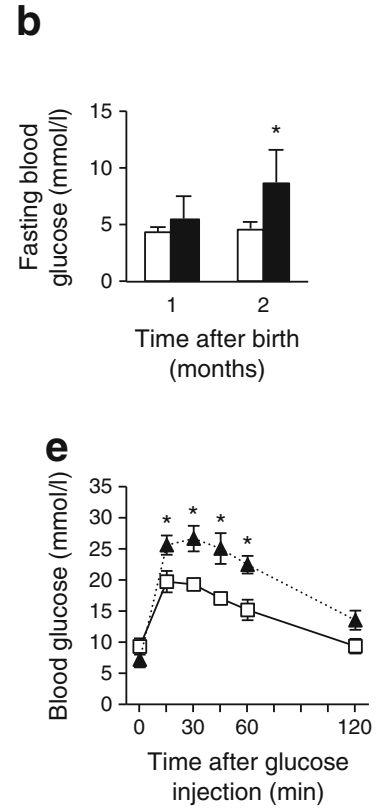

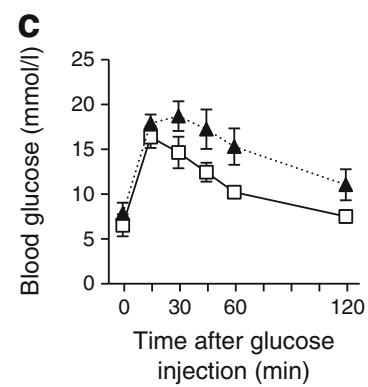

f

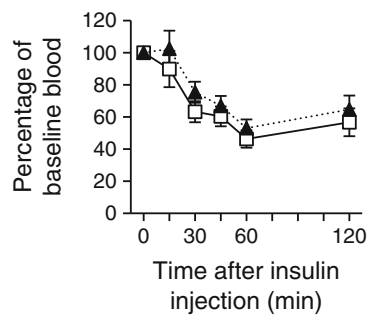




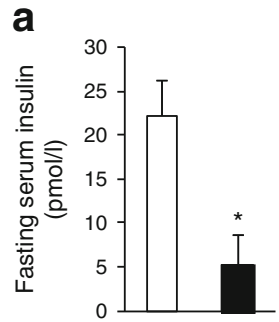

C

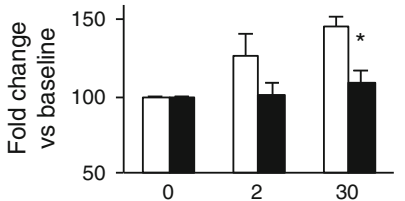

b

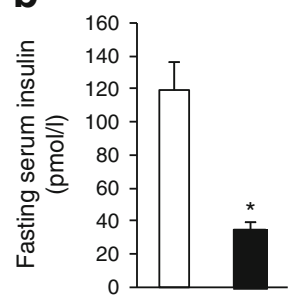

d

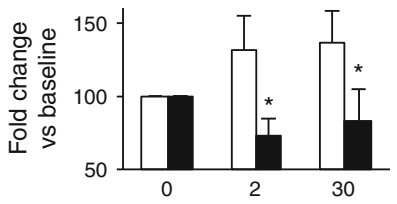

Fig. 3 Absence of HUWE1 leads to impaired insulin secretion in male Pdxlcre Huwe $^{\mathrm{fl} / \mathrm{y}}$ mice. $(\mathbf{a}, \mathbf{b})$ Fasting serum insulin and (c, d) GSIS of Pdxlcre Huwel ${ }^{+/ \mathrm{y}}(+/ \mathrm{Y})$ and Pdxlcre Huwel ${ }^{+}{ }^{\mathrm{fl} / \mathrm{y}}(-/ \mathrm{Y})$ mice at 2 months $(\mathbf{a}, \mathbf{c})$ and 6 months $(\mathbf{b}, \mathbf{d})$ of age $(n=5) .{ }^{*} p<0.05 \mathrm{vs}+/ \mathrm{Y}$ mice at the same age. White bars, $+/$ Y; black bars, $-/ Y$

6 months of age (Fig. 4c and ESM Fig. 4c), suggesting that Huwel deletion did not affect cellular proliferation. However, the number of TUNEL-positive cells was significantly elevated in Pdxlcre Huwe ${ }^{\mathrm{fl} / \mathrm{y}}$ islets at 2 months of age (ESM Fig. 4d, e) and furthermore at 6 months of age (Fig. 4d, e), consistent with the worse insulin secretion and glucose intolerance with age. The numbers of alpha cells undergoing apoptosis were very small in both genotypes and total alpha cell area did not appear diminished (ESM Fig. 4f).

Also, despite the increased apoptotic cells within their islets, gross architecture was intact (Fig. 4d and ESM Fig. 4d) and overall pancreas weight was not different between genotypes (ESM Fig. 2b, d). Thus, impairment in glucose homeostasis in Pdxlcre Huwe $^{\mathrm{fl} / \mathrm{y}}$ mice is most likely attributable to increased beta cell apoptosis resulting in reduced total insulinsecreting beta cell mass.

Individual beta cells from 6 month old male Pdxlcre ${ }^{+}$ Huwe $P^{f l y}$ mice demonstrated secretory dysfunction To directly examine the insulin secretory function of individual beta cells in the male $P d x 1 \mathrm{cre}^{+} \mathrm{Huwel}^{\mathrm{fl} / \mathrm{y}}$ mice, we employed patch-clamp $\mathrm{Cm}$ measurements of single isolated beta cells. When compared with age-matched controls, the $C \mathrm{~m}$ increase in beta cell isolated from 2-month-old Pdxlcre ${ }^{+}$Huwe $^{\mathrm{fl} / \mathrm{y}}$ mice did not differ significantly with each depolarising pulse (Fig. 5a, b). The size of the readily releasable pool (RRP) of granules $\left(\Delta C \mathrm{~m}_{1 \mathrm{st}-2 \text { nd }}\right.$ pulse $)$ also showed no significant difference in Pdxlcre Huwe $^{\mathrm{fl} / \mathrm{y}}$ cell $(28.5 \pm 6.8 \mathrm{fF} / \mathrm{pF})$ when compared with controls $(16.9 \pm 4 \mathrm{fF} / \mathrm{pF})$ (Fig. 5c). In addition, the rate of granule refilling/mobilisation $\left(\Delta C \mathrm{~m}_{3 \mathrm{rd}-10 \text { th }}\right.$ pulse $)$ was comparable between genotypes at 2 months of age (Fig. 5c). However, when the experiments were performed with beta cells isolated from mice at 6 months of age, $\mathrm{Cm}$ showed a stepwise decline with each pulsation in beta cells of Pdxlcre Huwel $^{\mathrm{fl} / \mathrm{y}}$ mice (Fig. 5d), which translated into a significant reduction in granule refilling/mobilisation rate (Fig. 5e). These results suggested that the mild glucose intolerance and reduction in circulating insulin a
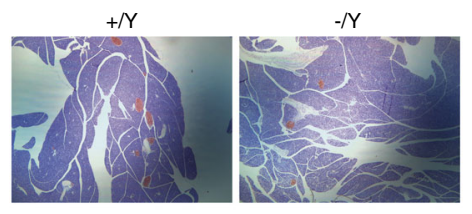

d
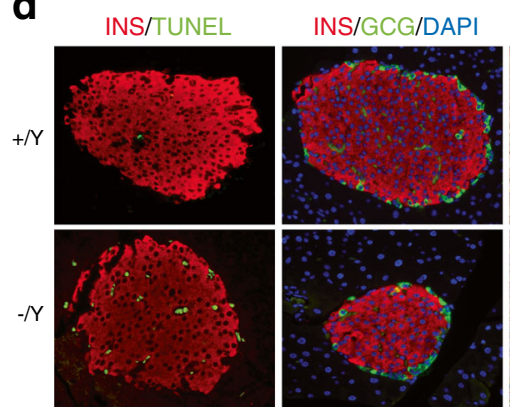

b



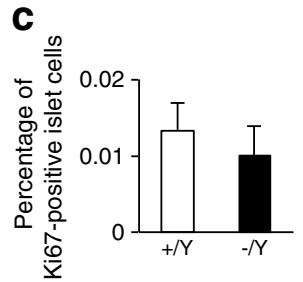

e

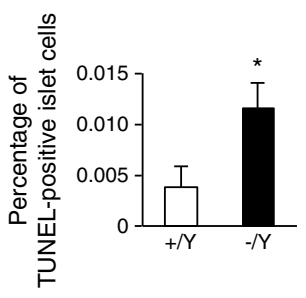

Fig. 4 Absence of HUWE1 leads to an increase in beta cell apoptosis and reduced beta cell area in 6-month-old Pdxlcre Huwe ${ }^{+1 / y}$ mice. (a) Representative pancreatic sections with immunohistochemical staining of insulin ( $\times 4$ magnification) and (b) quantification of beta cell area of $\mathrm{Pdxlcre}^{+} \mathrm{Huwel}^{+/ \mathrm{y}}(+/ \mathrm{Y})$ and PdxI cre $\mathrm{Huwel}^{+\mathrm{f} / \mathrm{y}}(-/ \mathrm{Y})$ mice at 6 months of age $(n=5)$. (c) Percentage Ki67-positive islet cells at 6 months of age $(n=5)$. (d) Representative pancreatic sections with immunofluorescent staining of insulin/TUNEL, insulin/glucagon/DAPI and immunohistochemical staining of GLUT2 and PDX1 ( $\times 20$ magnification) at 6 months of age $(n=5)$. (e) Percentage of TUNEL-positive islet cells at 6 months of age $(n=5) .{ }^{*} p<0.05$. White bars, $+/$ Y; black bars, $-/$ Y. GCG, glucagon; INS, insulin 
Fig. 5 Huwel deletion in beta cells leads to age-dependent reduction in exocytosis. (a) Cell capacitance for each pulse during the train of ten $500 \mathrm{~ms}$ depolarisations in beta cells isolated from Pdxlcre Huwe $I^{+/ y}$ $(+/ \mathrm{Y})$ and $P d x l$ cre $^{+}$Huwe $^{\mathrm{fl} / \mathrm{y}}$ $(-/ Y)$ mice $(n=12)$. (b) Cumulative changes in cell capacitance normalised to basal cell $\mathrm{Cm}(\mathrm{fF} / \mathrm{pF})$ in beta cells at 2 months of age $(n=10)$. (c) The size of the RRP of insulin granules $\left(\Delta C \mathrm{~m}_{1 \mathrm{st}-2 \mathrm{nd} \text { pulse }}\right)$ and the rate of granule mobilisation $\left(\Delta C \mathrm{~m}_{3 \text { rd-10th pulse }}\right)$ in beta cells isolated at 2 months of age $(n=10)$. (d) Cumulative changes in cell capacitance normalised to basal cell $C \mathrm{~m}(\mathrm{fF} / \mathrm{pF})$ in beta cells at 6 months of age $(n=12)$. (e) Size of the RRP of insulin granules $\left(\Delta C \mathrm{~m}_{1 \mathrm{st}-2 \mathrm{nd} \text { pulse }}\right)$ and the rate of granule mobilisation $\left(\Delta C \mathrm{~m}_{3 \mathrm{rd}-10 \text { th pulse }}\right)$ in beta cells at 6 months of age $(n=12)$. (f) Western blotting and quantification of phospho-Akt, Akt, phospho-AMPK, AMPK, cleaved caspase 3, GLUT2, PDX1, p53, MCL1, DNA polymerase beta and actin levels in isolated islets at 2 months of age $(n=3) .{ }^{*} p<0.05 \mathrm{vs}+/ \mathrm{Y}$ mice. White bars/squares, + /Y; black bars/triangles, $-/ Y$
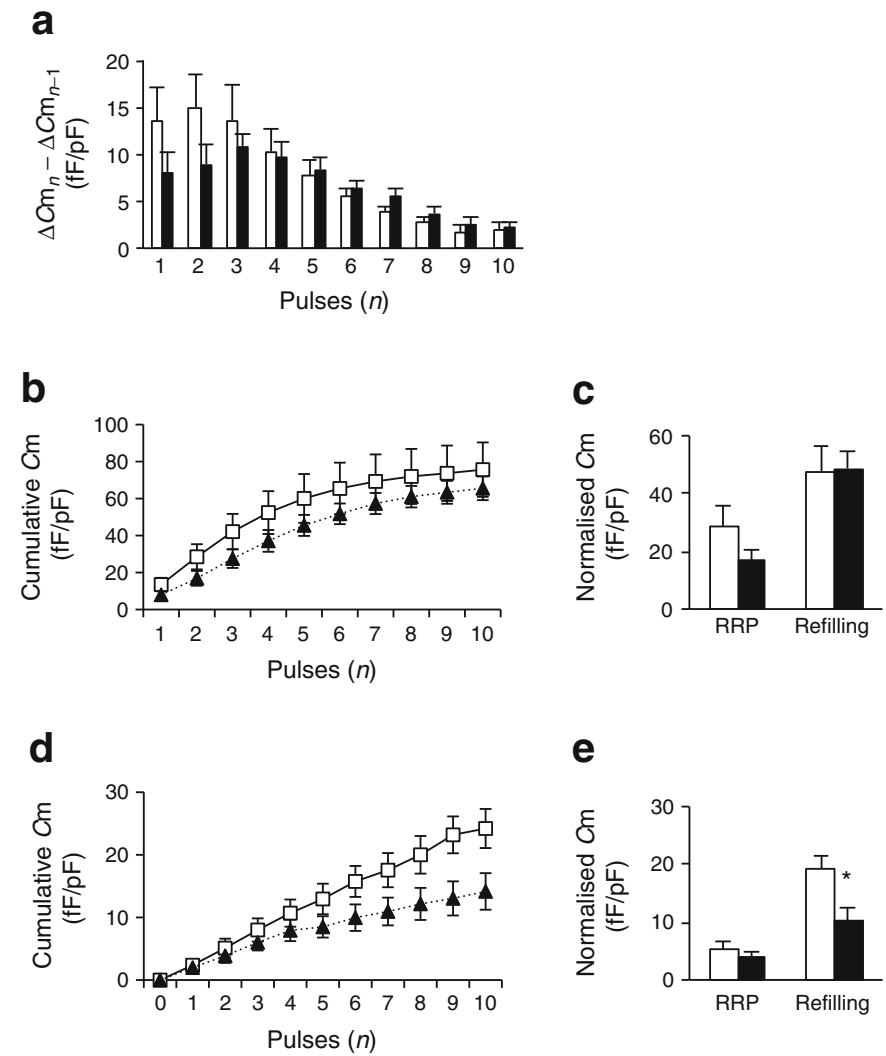

in young $P d x$ cre $^{+}$Huwe $^{\mathrm{fl} / \mathrm{y}}$ mice was primarily due to reduced beta cell mass likely from increased apoptosis while secretory function of individual beta cells was not affected. Conversely, both beta cell mass and secretory function were diminished in islets of older $P d x l$ cre $^{+} \mathrm{Huwel}^{\mathrm{f} / \mathrm{y}}$ mice, and this contributed to impaired glucose homeostasis.

Huwe1 deletion preferentially activated p53-dependent apoptotic machinery Multiple polyubiquitination and degradation substrates of HUWE1 have been identified. Among them, p53, MCL1 and DNA polymerase beta are better characterised [16, 20, 33]. Intriguingly, p53 induces apoptosis while MCL-1 and DNA polymerase inhibit the apoptotic pathway. Thus, HUWE1 seemingly regulates two opposing

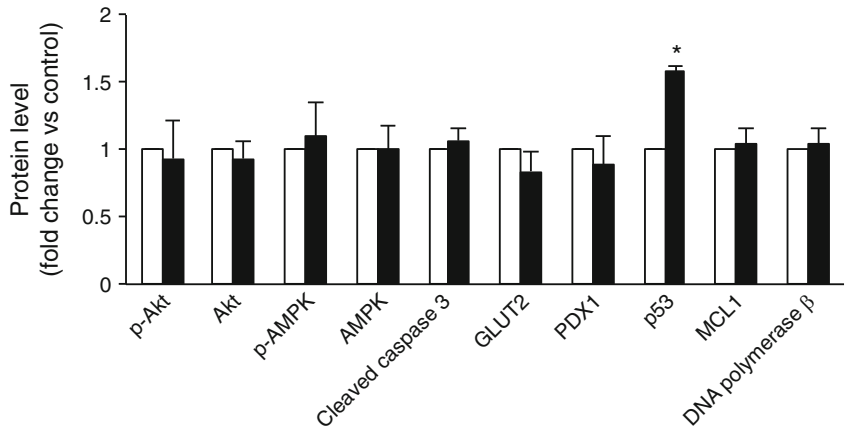

pathways involved in cell survival. To identify the signalling alterations that may have resulted from Huwel deletion in the pancreas in vivo, we measured the activation of p53 and MCL1 pathways. We found that Huwel deletion in islets led to increased p53 in Pdxlcre Huwe $^{\mathrm{fl} / \mathrm{y}}$ mice at 2 months of age (Fig. 5f), with an even more significant difference in older mice at 6 months of age (ESM Fig. 5a). In keeping with the well-known pro-apoptotic role of $\mathrm{p} 53$, there was an associated increase in cleaved caspase 3 (ESM Fig. 5a). In comparison, levels of MCL1 and DNA polymerase beta were not significantly different between $P d x l$ cre $^{+}$Huwe $^{\mathrm{fl} / \mathrm{y}}$ and control islets (Fig. 5f and ESM Fig. 5a). Therefore, p53-dependent apoptosis in HUWE1-deficient islets likely contributed to reduced beta cell mass and glucose intolerance in Pdxlcre Huwe $^{\mathrm{ff} / \mathrm{y}}$ 
a

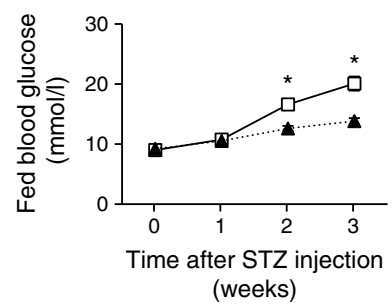

d

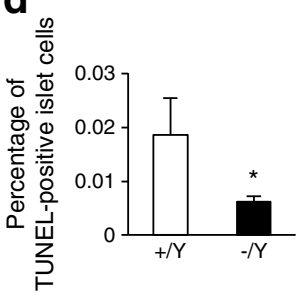

f

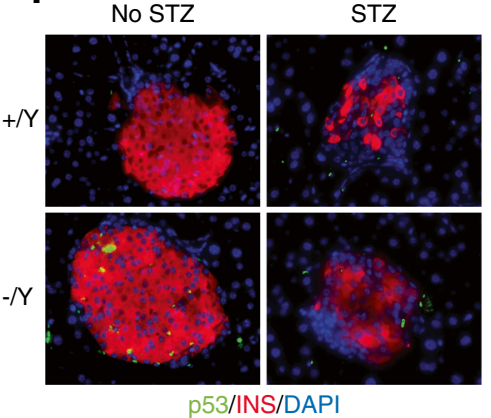

b

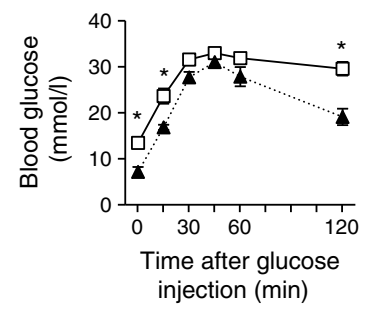

e

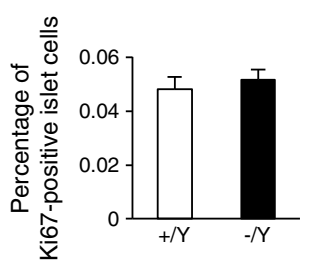

C



\section{No STZ}

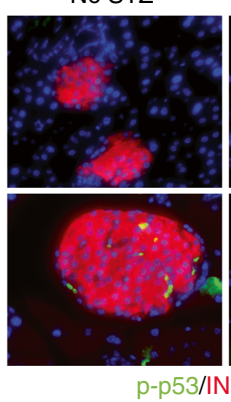

STZ



S/DAPI
No STZ

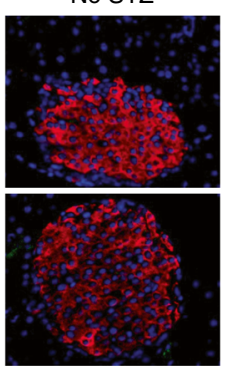

MCL1/INS/DAPI
Fig. 6 Pancreas-specific deletion of Huwel protects against MLDSinduced beta cell apoptosis. (a) Fed blood glucose in male Pdxlcre Huwe $^{+/ \mathrm{y}}(+/ \mathrm{Y})$ and Pdxlcre Huwe $^{\mathrm{fl} / \mathrm{y}}(-/ \mathrm{Y})$ mice at 2 months of age after MLDS injections $(n=5)$. (b) Glucose tolerance test and (c) fasting serum insulin of 2-month-old mice 3 weeks after MLDS $(n=5)$. (d) Percentage of TUNEL-positive and (e) Ki67-positive islet cells

mice, while Huwel deletion in islets had minimal effect on pro-survival pathways, such as p-Akt, p-AMPK, MCL1 and DNA polymerase beta (Fig. $5 \mathrm{f}$ and ESM Fig. 5a). Consistent with reduction in beta cell secretory function at 6 months of age, beta cell differentiation marker PDX1 also showed a reduction, while glucose-sensing receptor GLUT2 was similar in HUWE1-deficient islets compared with controls (Fig. $5 \mathrm{f}$ and ESM Fig. 5a). Coupled with reduced granule filling/ mobilising rate we observed in individual beta cells, these findings suggest that glucose intolerance in HUWE1deficient mice is due to both a defect in exocytosis and survival of pancreatic beta cells.

HUWE1 deletion paradoxically leads to protection against STZ-induced beta cell apoptosis The biological role of HUWE1 is highly specific for the cell type and is contextdependent. As such, HUWE1-deficient B lymphocytes demonstrated reduced viability under basal condition, while under genotoxic stress, they were resistant to apoptosis [17]. To test of 2-month-old mice 3 weeks after MLDS $(n=5)$. (c) Representative pancreatic sections with immunofluorescent staining of $\mathrm{p} 53$ / insulin (INS)/DAPI, phospho (p)-p53/INS/DAPI and MCL1/INS/ DAPI $\left(\times 20\right.$ magnification). ${ }^{*} p<0.05$ vs $+/ Y$ mice. White squares, $+/$ Y, black triangles, $-/ Y$. INS, insulin

whether this context-dependent divergent biological role of HUWE1 occurred in pancreatic beta cells, we used an MLDS model to induce beta cell apoptosis in vivo. Consistent with the protective role of Huwel deletion under cytotoxic conditions, Pdxlcre ${ }^{+}$Huwe $^{\mathrm{fl} / \mathrm{y}}$ mice were protected against hyperglycaemia and glucose intolerance after STZ injection (Fig. 6a, b). Consistent with more viable beta cells and better glucose tolerance after STZ injection in HUWE1-deficient mice, insulin levels were higher compared with controls (Fig. 6c). There was also a significant reduction in the percentage of TUNEL-positive cells when compared with control mice (Fig. 6d), while islet proliferation remained comparable after STZ injection between genotypes (Fig. 6e). While higher levels of p53 and phosphorylated p53 were seen in islets under basal conditions, no significant difference in p53 or p-p53 levels were detected with STZ treatment between Pdxlcre ${ }^{+}$ Huwe $\mathrm{I}^{\mathrm{fl} / \mathrm{y}}$ and littermate control mice (Fig. 6f, ESM Fig. 5e). MCL1 also did not differ significantly between genotypes, suggesting that HUWE1 regulates these substrates differently 
in distinct settings (Fig. 6f, ESM Fig. 5c). Thus, the biological role of HUWE1 is highly dependent on context in pancreatic beta cells. Under basal conditions, HUWE1 deletion leads to p53 stabilisation and an increase in apoptosis, whereas on DNA-damaging stress, HUWE1-deficient islets are protected against apoptosis in vivo.

\section{Discussion}

HUWE1 is a newly discovered apoptosis regulator that acts via its E3 ligase activity, which polyubiquitinates known players in apoptosis. Intriguingly, these HUWE1 targets consist of effectors of both pro-apoptotic and anti-apoptotic pathways, thus the precise function of HUWE1 in beta cells was unknown. This study showed that HUWE1 modulated beta cell homeostasis by exerting a tonic inhibition on p53dependent apoptosis in beta cells, such that pancreas-specific Huwel deletion led to increased beta cell death and glucose intolerance in mice under basal conditions. In contrast, HUWE1 appeared to play an opposite role when beta cells were under genotoxic stress. As such, the same HUWE1deficient mice were paradoxically protected against MLDSinduced beta cell apoptosis and diabetes. This protection was not associated with a significant difference in expression of GLUT2, which is required for STZ action. Rather, these findings suggest that HUWE1 can regulate substrates such as p53 differently in specific settings, similar to the recent report on the dual role of HUWE1 in regulation of B lymphocyte survival and proliferation [17]. HUWE1 demonstrated similar dual function in pancreatic beta cells, depending on the experimental context in which the role of HUWE1 was examined.

In agreement with the physiological pro-survival role of HUWE1, Kon and colleagues reported that rat insulin promoter (RIP)-mediated Huwel deletion in pancreatic beta cells led to similar beta cell apoptosis and diabetes starting at 6 months of age [34]. However, the possibility of RIPmediated effects in the central nervous system shown by other groups [35-37] was not explored in their study. On the other hand, the hypothalamic expression pattern of PDX1 is much more restricted [38]. This was further supported in our mice where we used $P d x l$-promoter-driven deletion of Huwel, which resulted in no change in hypothalamic HUWE1 expression or peripheral insulin sensitivity. Furthermore, the region of the Huwel gene that was targeted was different between the two groups (loxP sites flanked exon 11 in the report by Kon et al, whereas we used mice with loxP sites flanking exons 76 and 77) [34]. This difference is reflected in the early embryonic lethality (E12.5) of the whole-body knockout using the targeting construct used in our study, whereas perinatal lethality was observed by Kon et al [17, 34]. These differences suggest a more complete genetic ablation in mice that we used for our study in comparison to the report by Kon et al [17, 34].
Multiple HUWE1 substrates have been identified; among them is v-myc avian myelocytomatosis viral oncogene homologue (c-Myc) $[18,39]$. Huwel deletion leads to accumulation of c-Myc/zinc finger and BTB domain containing 17 (MIZ1) complex and subsequent downregulation of p21 in models of skin carcinogenesis [39]. Interestingly, in pancreatic beta cells, the absence of HUWE1 does not appear to have an impact on cell proliferation. It is possible that the intrinsic properties of low mitotic activity in these endocrine cells render them resistant against uncontrolled proliferation and tumorigenesis. Alternatively, this difference in HUWE1 function is a reflection of its context- and cell-type-dependent specificity in its biological role, which is highlighted by our findings in this report. Similarly, while HUWE1 can facilitate degradation of anti-apoptotic MCL1 [21, 24, 40], deletion of HUWE1 in the pancreas did not change MCL1 protein expression. This is consistent with the only slight differences in MCL1 that were seen at steady state in B lymphocytes with Huwel deletion, suggesting MCL1 regulation is context-specific [18, 24]. In addition to the essential role of HUWE1 in determining beta cell survival, we also showed an age-dependent decline in secretory function. Thus, the role of HUWE1 may be more complex than previously thought. Indeed, HUWE1 has been shown to modulate histone ubiquitination and chromatin condensation in addition to its role in cellular survival [19]. Therefore, HUWE1 deletion may have a wide range of effects on protein expression important in other areas of cellular function, including potentially the machinery required for insulin granule secretion as suggested by our data showing a defect in exocytosis in Pdxlcre Huwe $\mathrm{I}^{\mathrm{fl} / \mathrm{y}}$ beta cells.

In summary, our study shows HUWE1 is an important physiological regulator of both beta cell function and survival, such that Huwel deletion activates p53-dependent apoptosis and impairs beta cell secretory function with ageing under basal conditions. In contrast, HUWE1 has an opposite role under genotoxic conditions such that Huwel deletion provides protection against further apoptosis. These complexities in the roles of molecules that determine beta cell fate illustrate the need for clearer understanding of their intricacies as we strive to find novel therapeutic targets that enhance beta cell survival and function for treatment of both type 1 and type 2 diabetes.

Funding This work was supported by grants to MW from the Canadian Institutes of Health Research (CIHR) MOP-93707 and Canadian Diabetes Association (CDA), and to HG from CIHR MOP 86544. LW was supported by a Frederick Banting and Charles Best Canada Graduate Scholarship from CIHR, a Novo Nordisk graduate scholarship from the Banting and Best Diabetes Centre (BBDC), a Canada Graduate Scholarship from the Natural Sciences and Engineering Research Council of Canada (NSERC) and a Comprehensive Research Experience for Medical Students (CREMS) scholarship from the Faculty of Medicine, University of Toronto. CTL is supported by the Eliot Phillipson Clinician Scientist Training Program and a BBDC Postdoctoral Fellowship. EPC is supported by the CDA Doctoral Student Research Award. MW is 
supported by a Canada Research Chair in Signal Transduction in Diabetes Pathogenesis.

Duality of interest The authors declare that there is no duality of interest associated with this manuscript.

Contribution statement All authors contributed to conception, data, revising the manuscript, and approved the final version of the manuscript. LW and CTL performed experiments, analysed and interpreted data, drafted the manuscript and contributed to the study design. SAS developed methods and animal models, performed experiments, analysed and interpreted data. AMS, XL and EPC performed experiments, analysed and interpreted data. HG and PEM contributed to study design and discussion. ZH and TWM developed animal models and contributed to study design. MW supervised the project and developed the study design. MW is the guarantor of this work.

\section{References}

1. Faideau B, Larger E, Lepault F, Carel JC, Boitard C (2005) Role of beta-cells in type 1 diabetes pathogenesis. Diabetes 54(Suppl 2):S87-S96

2. DeFronzo RA, Ferrannini E (1991) Insulin resistance. A multifaceted syndrome responsible for NIDDM, obesity, hypertension, dyslipidemia, and atherosclerotic cardiovascular disease. Diabetes Care 14: 173-194

3. Donath MY, Halban PA (2004) Decreased beta-cell mass in diabetes: significance, mechanisms and therapeutic implications. Diabetologia 47:581-589

4. Kruse JP, Gu W (2009) Modes of p53 regulation. Cell 137:609-622

5. Vousden KH, Prives C (2009) Blinded by the light: the growing complexity of p53. Cell 137:413-431

6. Messmer UK, Ankarcrona M, Nicotera P, Brune B (1994) p53 expression in nitric oxide-induced apoptosis. FEBS Lett 355: 23-26

7. Zhang S, Liu J, Saafi EL, Cooper GJ (1999) Induction of apoptosis by human amylin in RINm5F islet beta-cells is associated with enhanced expression of p53 and p21WAF1/CIP1. FEBS Lett 455: $315-320$

8. Gurzov EN, Germano CM, Cunha DA et al (2010) p53 up-regulated modulator of apoptosis (PUMA) activation contributes to pancreatic beta-cell apoptosis induced by proinflammatory cytokines and endoplasmic reticulum stress. J Biol Chem 285: 19910-19920

9. Cnop M, Welsh N, Jonas JC, Jorns A, Lenzen S, Eizirik DL (2005) Mechanisms of pancreatic beta-cell death in type 1 and type 2 diabetes: many differences, few similarities. Diabetes 54(Suppl 2): S97-S107

10. Wrede CE, Dickson LM, Lingohr MK, Briaud I, Rhodes CJ (2002) Protein kinase B/Akt prevents fatty acid-induced apoptosis in pancreatic beta-cells (INS-1). J Biol Chem 277: 49676-49684

11. Hoshino A, Ariyoshi M, Okawa Y et al (2014) Inhibition of p53 preserves Parkin-mediated mitophagy and pancreatic $\beta$-cell function in diabetes. Proc Natl Acad Sci U S A 111:3116-3121

12. Marine JC, Lozano G (2010) Mdm2-mediated ubiquitylation: p53 and beyond. Cell Death Differ 17:93-102

13. Ringshausen I, O'Shea CC, Finch AJ, Swigart LB, Evan GI (2006) $\mathrm{Mdm} 2$ is critically and continuously required to suppress lethal p53 activity in vivo. Cancer Cell 10:501-514

14. Dornan D, Wertz I, Shimizu H et al (2004) The ubiquitin ligase COP1 is a critical negative regulator of $\mathrm{p} 53$. Nature 429:86-92
15. Leng RP, Lin Y, Ma W et al (2003) Pirh2, a p53-induced ubiquitin-protein ligase, promotes p53 degradation. Cell 112: 779-791

16. Chen D, Kon N, Li M, Zhang W, Qin J, Gu W (2005) ARF-BP1/ Mule is a critical mediator of the ARF tumor suppressor. Cell 121: $1071-1083$

17. Hao Z, Duncan GS, Su YW et al (2012) The E3 ubiquitin ligase Mule acts through the ATM-p53 axis to maintain B lymphocyte homeostasis. J Exp Med 209:173-186

18. Adhikary S, Marinoni F, Hock A et al (2005) The ubiquitin ligase HectH9 regulates transcriptional activation by Myc and is essential for tumor cell proliferation. Cell 123:409-421

19. Liu Z, Oughtred R, Wing SS (2005) Characterization of E3Histone, a novel testis ubiquitin protein ligase which ubiquitinates histones. Mol Cell Biol 25:2819-2831

20. Zhong Q, Gao W, Du F, Wang X (2005) Mule/ARF-BP1, a BH3-only E3 ubiquitin ligase, catalyzes the polyubiquitination of Mcl-1 and regulates apoptosis. Cell 121:1085-1095

21. Hall JR, Kow E, Nevis KR et al (2007) Cde6 stability is regulated by the Huwe1 ubiquitin ligase after DNA damage. Mol Biol Cell 18: 3340-3350

22. Zhao X, Heng JI, Guardavaccaro D et al (2008) The HECT-domain ubiquitin ligase Huwe1 controls neural differentiation and proliferation by destabilizing the N-Myc oncoprotein. Nat Cell Biol 10:643-653

23. Yang T, Buchan HL, Townsend KJ, Craig RW (1996) MCL-1, a member of the BLC-2 family, is induced rapidly in response to signals for cell differentiation or death, but not to signals for cell proliferation. J Cell Physiol 166:523-536

24. Rolfo A, Garcia J, Todros T, Post M, Caniggia I (2012) The double life of MULE in preeclamptic and IUGR placentae. Cell Death Dis 3:e305

25. Cai EP, Wu X, Schroer SA et al (2013) Retinoblastoma tumor suppressor protein in pancreatic progenitors controls $\alpha$ - and $\beta$-cell fate. Proc Natl Acad Sci U S A 110:14723-14728

26. Herrera PL (2000) Adult insulin- and glucagon-producing cells differentiate from two independent cell lineages. Development 127: 2317-2322

27. Nguyen KT, Tajmir P, Lin CH et al (2006) Essential role of Pten in body size determination and pancreatic beta-cell homeostasis in vivo. Mol Cell Biol 26:4511-4518

28. Wang L, Liu Y, Yan Lu S et al (2010) Deletion of Pten in pancreatic $\beta$-cells protects against deficient $\beta$-cell mass and function in mouse models of type 2 diabetes. Diabetes 59:3117-3126

29. Liadis N, Salmena L, Kwan E et al (2007) Distinct in vivo roles of caspase- 8 in beta-cells in physiological and diabetes models. Diabetes 56:2302-2311

30. Choi D, Schroer SA, Lu SY et al (2010) Erythropoietin protects against diabetes through direct effects on pancreatic beta cells. J Exp Med 207:2831-2842

31. Le May C, Chu K, Hu M et al (2006) Estrogens protect pancreatic beta-cells from apoptosis and prevent insulin-deficient diabetes mellitus in mice. Proc Natl Acad Sci U S A 103:92329237

32. Tiano JP, Mauvais-Jarvis F (2012) Importance of oestrogen receptors to preserve functional $\beta$-cell mass in diabetes. Nat Rev Endocrinol 8: 342-351

33. Parsons JL, Tait PS, Finch D et al (2009) Ubiquitin ligase ARF-BP1/Mule modulates base excision repair. EMBO J 28: $3207-3215$

34. Kon N, Zhong J, Qiang L, Accili D, Gu W (2012) Inactivation of arf-bp1 induces p53 activation and diabetic phenotypes in mice. J Biol Chem 287:5102-5111

35. Choudhury AI, Heffron H, Smith MA et al (2005) The role of insulin receptor substrate 2 in hypothalamic and beta cell function. J Clin Invest 115:940-950 
36. Gannon M, Shiota C, Postic C, Wright CV, Magnuson M (2000) Analysis of the Cre-mediated recombination driven by rat insulin promoter in embryonic and adult mouse pancreas. Genesis 26:139-142

37. Wang L, Opland D, Tsai S et al (2014) Pten deletion in RIP-Cre neurons protects against type 2 diabetes by activating the antiinflammatory reflex. Nat Med 20:484-492

38. Wicksteed B, Brissova M, Yan W et al (2010) Conditional gene targeting in mouse pancreatic $\beta$-cells: analysis of ectopic Cre transgene expression in the brain. Diabetes 59:3090-3098

39. Inoue S, Hao Z, Elia AJ et al (2013) Mule/Huwe1/Arf-BP1 suppresses Ras-driven tumorigenesis by preventing c-Myc/Miz1mediated down-regulation of $\mathrm{p} 21$ and p15. Genes Dev 27:1101-1114

40. Warr MR, Mills JR, Nguyen M et al (2011) Mitochondriondependent $\mathrm{N}$-terminal processing of outer membrane Mcl-1 protein removes an essential Mule/Lasu1 protein-binding site. J Biol Chem 286:25098-25107 